\title{
Pengaruh Perubahan Nilai Tukar Rupiah Terhadap \\ Neraca Transaksi Berjalan Indonesia, Periode 1990.I - 2004.II \\ (Kasus Indonesia - Amerika Serikat) ${ }^{1}$
}

\section{The Effects of Rupiah Exchange Rate Changes on the Indonesia Current Accounts, Period of 1990.I - 2004.II (The Case of Indonesia - United States of America)}

\author{
Arintoko $^{2}$ dan Faried Wijaya ${ }^{3}$
}

\begin{abstract}
This research investigates the effects of exchange rate change on the relative current account and real GDP in Indonesia to US. This research provides time series evidence for the period of first quarter of 1990 to second quarter of 2004 under flexibel exchange rate regimes. The analysis is based on a J-Curve theory. First, this research employs unit root, cointegration and Granger causality tests and summarizes the relationships between real exchange rate, the current account, and real GDP. Second, the standard theoretical explanation of the JCurve effect is used to motivate a vector autoregression (VAR) and error correction mechanism (ECM) analysis of real exchange rate change on the relative current account, and real GDP for Indonesia to US. This research finds weak evidence of a J-Curve for the Indonesia current account, in fact these empirical results reject the J-Curve hypothesis. The empirical study finds little evidence that a currency depreciation causes a current account deficits in the short run in Indonesia-US bilateral data and no evidence of a reliable long run effect of exchange rate change on the current account. Interestingly, empirical results show that these evidence are not consistent with the standard theoretical explanation of the J-Curve. Consequently, these empirical results pose a strong challenge for international economic theory and policy.
\end{abstract}

Keywords : exchange rate change, current account, real GDP, and J-Curve theory

\footnotetext{
${ }^{1}$ Penelitian ini mendapatkan dukungan dana dari Pusat Pendidikan dan Studi Kebanksentralan (PPSK) Bank Indonesia tahun 2005

2 Staf pengajar Fakultas Ekonomi Universitas Teknologi "Yogyakarta" dan alumnus Magister Sains Ilmu Ekonomi Sekolah Pascasarjana UGM Yogyakarta.

${ }^{3}$ Staf pengajar Fakultas Ekonomi dan Magister Sains Ilmu Ekonomi Sekolah Pascasarjana Universitas Gadjah Mada Yogyakarta
} 


\section{PENDAHULUAN}

Adanya keterbukaan (openess) perekonomian memiliki dampak pada neraca pembayaran suatu negara yang menyangkut arus perdagangan dan lalu lintas modal terhadap luar negeri suatu negara. Arus perdagangan dapat dipengaruhi oleh kebijakan nilai tukar dalam upaya untuk menjaga daya saing ekspor dan menekan impor untuk mengurangi defisit transaksi berjalan yang sedang dialami.

Dengan mengamati perkembangan kinerja perdagangan Indonesia selama ini, terlihat bahwa nilai tukar masih digunakan sebagai alat oleh otoritas moneter untuk mendorong ekspor Indonesia (Waluyo dan Siswanto, 1998). Devaluasi di Indonesia pada saat menganut sistem nilai tukar tetap (fixed exchange rate) semula dilakukan untuk meningkatkan daya saing ekspor yang selanjutnya dapat menanggulangi defisit neraca pembayaran yang makin membengkak.

Setelah beberapa kali devaluasi dilakukan, bagaimanapun juga penggunaan suatu piranti untuk meningkatkan daya saing ekspor Indonesia menjadi tidak dapat bertahan kemanjurannya. Peningkatan yang cukup berarti pada penerimaan ekspor, khususnya dari sektor nonmigas menjadi terkikis karena cepatnya penyesuaian harga domestik akibat terlalu tingginya nilai rupiah terhadap dollar Amerika Serikat. Sejak tahun 1986 pemerintah menghentikan sistem nilai tukar tetap dan menerapkan kebijakan nilai tukar mengambang terkendali (managed floating exchange rate) sejak tahun 1987 dan diganti dengan sistem mengambang bebas (free floating exchange rate) sejak tahun 1997.

Sebenarnya cukup jelas arahnya bahwa devaluasi pada nilai tukar tetap atau depresiasi mata uang domestik menurut teori ekonomi internasional dan sejumlah studi empiris ditujukan untuk memperbaiki neraca transaksi berjalan suatu negara. Sebagaimana disampaikan Adelman (1999) bahwa apresiasi mata uang domestik akan menurunkan daya saing ekspor dan pada gilirannya akan menambah defisit transaksi berjalan, demikian pula dalam pengertian sebaliknya.

Namun demikian, pengalaman di Indonesia menunjukkan bahwa devaluasi menjadi tidak manjur, terlebih lagi dari studi empiris yang dilakukan oleh Leonard dan Stockman (2001) juga menunjukkan hubungan yang lemah antara nilai tukar riil, transaksi berjalan dan GDP riil. Sependapat dengan hasil hal itu, menurut Rajan (2003) bahwa depresiasi dan apresiasi mata uang bukan cara efektif mengoreksi ketidakseimbangan transaksi berjalan di Amerika Serikat.

Pertentangan antara teori ekonomi internasional dengan pengalaman devaluasi di Indonesia dan beberapa studi empiris di negara maju, membawa kepada isu yang menarik dan perlunya dilakukan studi bagaimana dampak sebenarnya dari depresiasi atau apresiasi rupiah terhadap perubahan neraca transaksi berjalan Indonesia yang selanjutnya menentukan neraca pembayarannya semenjak menetapkan kurs mengambang. Penelitian mengambil kasus Indonesia dengan Amerika Serikat karena hubungan perdagangan internasional yang cukup besar antara kedua negara tersebut serta mempertimbangkan mata uang dollar AS sebagai mata uang kuat, konvertibel dan banyak digunakan dalam berbagai transaksi internasional oleh Indonesia. 


\section{TINJAUAN TEORITIK DAN EMPIRIK}

\section{II.1. Neraca Transaksi Berjalan dan Mekanisme Penyesuaiannya}

Neraca transaksi berjalan (current account) terdiri dari neraca perdagangan yang mencatat ekspor (X) dan impor (M) barang/komoditi dan neraca jasa bersih, serta transfer. Sementara neraca modal (capital account) mencatat aliran modal jangka pendek dan jangka panjang antar negara. Neraca transaksi berjalan dan neraca modal merupakan dua bagian yang menentukan neraca pembayaran. Jika suatu negara mengalami surplus aliran modal dalam neraca modalnya, maka defisit atau surplusnya neraca transaksi berjalan akan menentukan posisi neraca pembayarannya. Sebaliknya, dalam kondisi suatu negara mengalami defisit neraca modalnya, maka besar kecilnya surplus transaksi berjalan akan menentukan kemungkinan dapat menutup atau tidak pada defisit pada neraca modalnya.

Dalam koreksi terhadap neraca transaksi berjalan, secara teoritik dilakukan melalui depresiasi mata uangnya terhadap defisit transaksi berjalan yang terjadi. Depresiasi akan mempengaruhi harga relatif dari barang yang diperdagangkan. Harga ekspor akan turun dan sebaliknya harga impor akan meningkat. Penurunan harga ekspor akan meningkatkan permintaan impor oleh luar negeri dan menurunkan permintaan impor dalam negeri. Namun demikian turunnya impor tidak hanya semata-mata disebabkan oleh depresiasi mata uangnya namun juga tingkat pendapatan nasional yang berubah dapat mempengaruhi permintaan impor negara itu. Penjelasan teori tersebut di atas dapat ditunjukkan dengan persamaan berikut ini (Dernburg, 1985).

$$
\begin{aligned}
& \mathrm{CA}=\mathrm{X}\left(\mathrm{e}, \mathrm{Y}^{*}\right)-\mathrm{M}(\mathrm{e}, \mathrm{Y}) \\
& \mathrm{CA}: \text { transaksi berjalan } \\
& \mathrm{X}: \text { ekspor } \\
& \mathrm{M}: \text { impor } \\
& \mathrm{e}: \text { kurs } \\
& \mathrm{Y}: \text { pendapatan nasional } \\
& \mathrm{Y}^{*}: \text { pendapatan luar negeri }
\end{aligned}
$$

\section{II.2. Efek Kurva-J}

Perubahan nilai tukar mata uang nasional suatu negara terhadap mata uang negara lain dapat memberikan efek terhadap perubahan transaksi berjalan yang dapat menyerupai seperti kurva-J. Depresiasi mata uang suatu negara tidak secara langsung memperbaiki neraca transaksi berjalannya, karena dalam jangka pendek akan memberikan efek negatif (memburuk) dan selanjutnya dalam jangka panjang depresiasi akan berdampak pada perbaikan neraca transaksi berjalan melalui kenaikan ekspor akibat meningkatnya daya saing internasional dan menurunnya impor karena efek pengalihan pengeluaran penduduk domestik, serta meningkatnya permintaan agregat oleh penduduk luar negeri terhadap produk domestik sehingga ekspor dan GDP riil juga meningkat. 


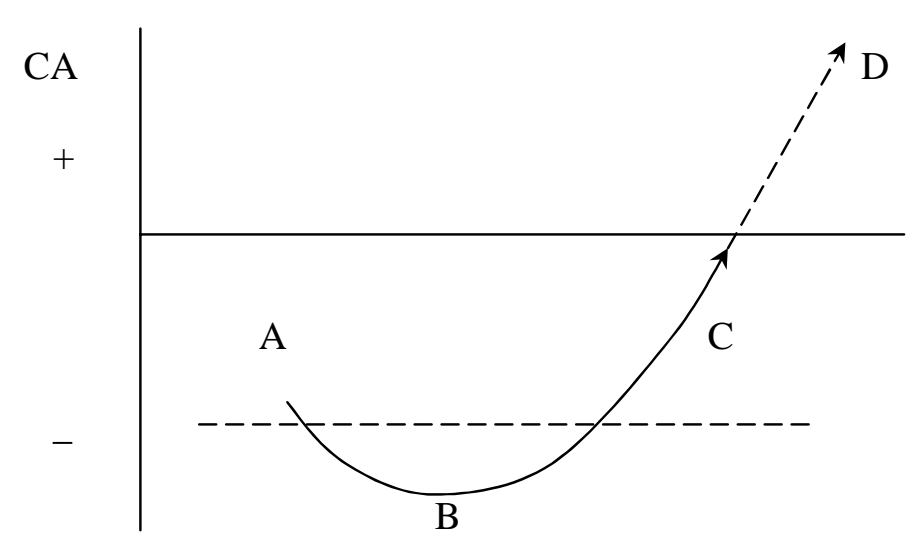

Gambar 1. Efek Kurva-J Perubahan Nilai Tukar terhadap Neraca Transaksi Berjalan

Dengan asumsi bahwa perekonomian dimulai pada posisi A yang ditandai dengan defisit transaksi berjalan yang selanjutnya menurunkan nilai tukar. Pada awalnya volume impor tidak berubah pada kontrak tertentu atas barang - barang impor. Bagaimanapun juga, depresiasi meningkatkan nilai mata uang domestik untuk impor yang menyebabkan pengeluaran total atas impor meningkat pada volume tertentu. Permintaan ekspor juga akan menjadi inelastik dalam merespon perubahan nilai tukar pada jangka pendek. Dalam hal ini pendapatan dari ekspor tidak cukup untuk mengkompensasi pengeluaran impor yang lebih tinggi. Defisit neraca transaksi berjalan dapat menjadi lebih buruk untuk beberapa bulan. Ini ditunjukkan oleh gerakan dari A ke B pada diagram di atas. Jika elastisitas permintaan ekspor dan impor lebih besar dari satu dalam jangka panjang neraca perdagangan akan membaik. Ini dikenal sebagai Marshall-Learner condition.

Dalam diagram di atas ditunjukkan adanya efek kurva-J, sebagaimana permintaan ekspor yang meningkat sementara konsumen domestik mengalihkan pengeluaran mereka dari impor barang dan jasa sehingga secara keseluruhan neraca pembayaran mulai membaik. Keadaan ini ditunjukkan oleh gerakan dari A ke C pada diagram tersebut. Perbaikan neraca transaksi berjalan secara berkelanjutan dapat dimungkinkan terjadi pembalikan arah dari defisit menjadi surplus sebagaimana ditunjukkan oleh arah panah putus-putus dari C ke D.

\section{II.3. Hasil Penelitian Sebelumnya}

Krugman dan Baldwin (1987), Eichenbaum dan Evans (1995), serta Foray dan McMillan (1999) menemukan adanya efek kurva-J dalam perilaku transaksi berjalan. Hasil penelitian lain yaitu penelitian Ma dan Cheng (2003) menemukan adanya efek krisis mata uang yang berdampak negatif terhadap impor tetapi 
berdampak positif terhadap ekspor. Merosotnya mata uang nasional mengurangi impor dalam jangka pendek dan menstimulasi ekspor dalam jangka panjang.

Di pihak lain Moffet (1989), Rose dan Yellen (1989), Leonard dan Stockman (2001) tidak menemukan adanya efek kurva-J pada perilaku transaksi berjalan di Amerika Serikat. Demikian pula hasil studi oleh Calderon et al. (2000) di negara-negara berkembang dan Lee dan Chinn (1998) di Inggris. Sementara penelitian mengenai perilaku neraca perdagangan yang pernah dilakukan Liew et al. (2003) di negara-negara ASEAN dan oleh Devkota (2004) di Nepal menunjukkan bahwa kebijakan penyesuaian melalui devaluasi tidak dapat memperoleh efek yang diinginkan dari perubahan nilai tukar terhadap neraca perdagangan.

Namun demikian penelitian Waluyo dan Siswanto (1998) menunjukkan bahwa elastisitas nilai tukar riil terhadap ekspor nonmigas yang cukup besar dan signifikan mengimplikasikan kebijakan depresiatif rupiah yang dilaksanakan beberapa waktu lalu di Indonesia cukup beralasan dalam mempengaruhi kinerja ekspor nonmigas, namun pengaruhnya tidak segera dan membutuhkan lag. Selain itu pengaruh nilai tukar dalam mendorong ekspor semakin besar dan semakin cepat dalam kurun waktu 1989.I - 1997.II.

\section{II.4. Landasan Teoritik Penelitian}

Depresiasi atau devaluasi yang menyebabkan ekspor meningkat dan impor menurun untuk mengurangi defisit neraca transaksi berjalan terjadi melalui berkurangnya defisit neraca perdagangan. Oleh karena itu, landasan teoritik dalam penelitian ini dapat disajikan sebagai berikut :

(1)

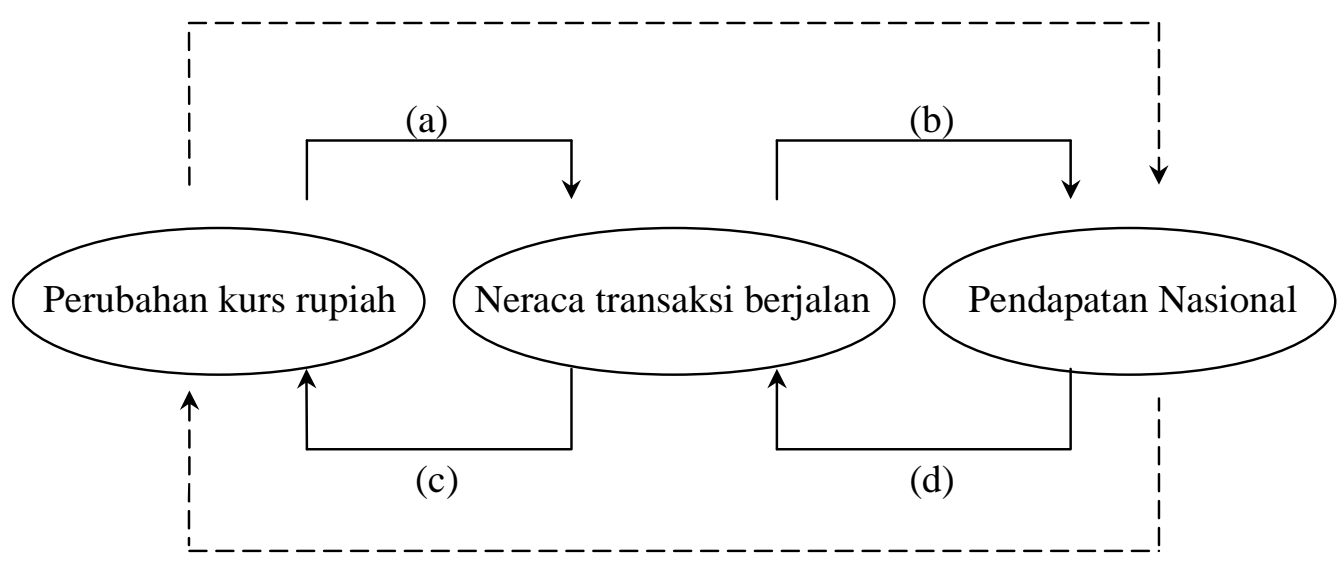

(2)

Gambar 2. Skema Hubungan antar Variabel Sebagai Kerangka Pikir Penelitian 
Skema hubungan antar variabel di atas merupakan hubungan kausalitas baik secara langsung (a, b, c, dan d) maupun tidak langsung (1 dan 2). Pada arah panah a dan c menunjukkan bahwa perubahan kurs rupiah akan berpengaruh terhadap neraca transaksi berjalan dan sebaliknya. Sementara pada arah panah b dan d menunjukkan pengaruh perubahan transaksi berjalan terhadap pendapatan nasional dan sebaliknya.

Hipotesis yang diajukan adalah hipotesis yang didasarkan pada teori kurva-J bahwa depresiasi rupiah dapat menyebabkan neraca transaksi berjalan memburuk dalam jangka pendek dan akan membaik melalui peningkatan ekspor neto sebagai akibat meningkatnya daya saing produk dalam negeri di pasar internasional dalam jangka panjang. Di pihak lain membaiknya (surplusnya) neraca transaksi berjalan mendorong apresiasi rupiah dan sebaliknya, sehingga proses penyesuaian transaksi berjalan dan kurs berlangsung secara terus-menerus dan otomatis.

Sementara itu perubahan neraca transaksi berjalan akan berdampak positif terhadap pendapatan nasional dan pengaruh sebaliknya. Membaiknya atau meningkatnya transaksi berjalan melalui peningkatan ekspor neto akan meningkatkan pendapatan nasional. Di pihak lain meningkatnya pendapatan nasional akan meningkatkan impor dan jika ekspor tidak meningkat melebihi naiknya impor maka dapat menurunkan neraca transaksi berjalan dan sebaliknya. Dengan demikian perubahan kurs rupiah dapat berpengaruh secara tidak langsung terhadap pendapatan nasional seperti ditunjukkan arah panah (1), dan sebaliknya pendapatan nasional berpengaruh secara tidak langsung terhadap kurs rupiah seperti ditunjukkan arah panah (2).

\section{METODOLOGI PENELITIAN}

\section{III.1. Model Analisis}

Model analisis yang digunakan dalam penelitian ini adalah vector autoregression (VAR) dan error correction model (ECM) dengan terlebih dahulu dilakukan uji kausalitas Granger dan uji akar-akar unit untuk mengetahui pada derajat berapa data yang diamati tersebut stasioner, serta uji kointegrasi.

\section{III.2. Uji Kointegrasi}

Uji kointegrasi dilakukan untuk menguji ada tidaknya hubungan jangka panjang di antara variabel-variabel yang diestimasi. Adanya hubungan jangka panjang (kointegrasi) antara variabel yang diestimasi mensyaratkan dapat dinyatakannya dalam model ECM dan VAR. Uji kointegrasi pada sistem multivariat ini digunakan pendekatan Johansen. Uji kointegrasi didasarkan dari formulasi model berikut (Verbeek, 2000) :

$$
\Delta Y_{t}=\Gamma_{1} \Delta Y_{t-1}+\ldots \ldots+\Gamma_{k-1} \Delta Y_{t-k+1}+\prod Y_{t-k}+\varepsilon_{t}
$$




$$
\begin{aligned}
& \mathrm{t}=\text { kuartal } \\
& \mathrm{k}=\text { jumlah kelambanan (lag) }
\end{aligned}
$$

Dalam pengujian hipotesis dengan pendekatan ini digunakan nilai statistik yang dinamakan Likelihood Ratio (LR) test statistic.

$$
Q_{r}=-T \sum_{i=r+1}^{k} \log \left(1-\lambda_{i}\right)
$$

untuk $\mathrm{r}=0, \ldots ., \mathrm{k}-1$ di mana $\lambda_{\mathrm{i}}$ merupakan nilai eigenvalue. $T$ adalah jumlah sampel. $Q_{\mathrm{r}}$ juga disebut trace statistic.

Variabel Y pada model 2 tersebut adalah variabel-variabel pada model VAR. Signifikannya parameter-parameter di atas mengandung informasi penyesuaian jangka pendek dan jangka panjang atas perubahan Y.

\section{III.3. Uji Kausalitas}

Adanya hubungan kausalitas antara dua variabel yang digunakan dalam model yang akan diestimasi dalam VAR sebaiknya diuji dahulu. Uji kausalitas dapat dilakukan dengan uji kausalitas Granger. Sebagai contoh, dua variabel Y dan $\mathrm{Z}$ berikut diuji hubungan kausalitasnya dengan persamaan berikut ini.

$$
\begin{aligned}
& \mathrm{Y}_{\mathrm{t}}=\sum_{i=1}^{n} \alpha_{\mathrm{i}} \mathrm{Y}_{\mathrm{t}-\mathrm{i}}+\sum_{j=1}^{n} \beta_{\mathrm{j}} \mathrm{Z}_{\mathrm{t}-\mathrm{j}}+u_{1 \mathrm{t}} \\
& \mathrm{Z}_{\mathrm{t}}=\sum_{i=1}^{n} \lambda_{\mathrm{i}} \mathrm{Z}_{\mathrm{t}-\mathrm{i}}+\sum_{j=1}^{n} \delta_{\mathrm{j}} \mathrm{Y}_{\mathrm{t}-\mathrm{j}}+u_{2 \mathrm{t}} \\
& \mathrm{t}=\text { kuartal } \\
& \mathrm{i}, \mathrm{j}=\text { jumlah kelambanan (lag) kuartal }
\end{aligned}
$$

Variabel $\mathrm{Y}$ dan $\mathrm{Z}$ di atas yaitu nilai tukar rupiah riil, neraca transaksi berjalan (diuji pula terhadap ekspor dan impor) serta GDP riil secara berpasangan.

\section{III.4. Model VAR}

Model VAR yang digunakan terdiri dari 3 variabel endogen yaitu nilai transaksi berjalan relatif Indonesia - AS (CA), tukar rupiah rupiah riil atas dollar AS (RER), dan PDB atau GDP riil relatif Indonesia terhadap AS (GDP).

$$
\begin{aligned}
& \mathrm{CA}_{\mathrm{t}}=\alpha_{1}+\sum_{j=1}^{k} \beta_{1 \mathrm{j}} \mathrm{CA}_{\mathrm{t}-\mathrm{j}}+\sum_{j=1}^{k} \gamma_{1 \mathrm{j}} \mathrm{RER}_{\mathrm{t}-\mathrm{j}}+\sum_{j=1}^{k} \varphi_{1 \mathrm{j}} \mathrm{GDP}_{\mathrm{t}-\mathrm{j}}+e_{1 \mathrm{t}} \\
& \mathrm{RER}_{\mathrm{t}}=\alpha_{2}+\sum_{j=1}^{k} \beta_{2 \mathrm{j}} \mathrm{RER}_{\mathrm{t}-\mathrm{j}}+\sum_{j=1}^{k} \gamma_{2 \mathrm{j}} \mathrm{GDP}_{\mathrm{t}-\mathrm{j}}+\sum_{j=1}^{k} \varphi_{2 \mathrm{j}} \mathrm{CA}_{\mathrm{t}-\mathrm{j}}+e_{2 \mathrm{t}} \\
& \mathrm{GDP}_{\mathrm{t}}=\alpha_{3}+\sum_{j=1}^{k} \beta_{3 \mathrm{j}} \mathrm{GDP}_{\mathrm{t}-\mathrm{j}}+\sum_{j=1}^{k} \gamma_{3 \mathrm{j}} \mathrm{CA}_{\mathrm{t}-\mathrm{j}}+\sum_{j=1}^{k} \varphi_{3 \mathrm{j}} \mathrm{RER}_{\mathrm{t}-\mathrm{j}}+e_{3 \mathrm{t}}
\end{aligned}
$$




$$
\begin{aligned}
& C A \equiv \frac{C A_{I N D}}{G D P_{I N D}}-\frac{C A_{A S}}{G D P_{A S}} \\
& \mathrm{RER} \equiv \in=\mathrm{e} \times\left(\mathrm{P} / \mathrm{P}^{*}\right) \\
& G D P \equiv \frac{G D P_{I N D}}{G D P_{A S}}
\end{aligned}
$$

$\mathrm{t}=$ kuartal

$\mathrm{j}=$ jumlah lag (kelambanan) kuartal yang dipilih berdasarkan estimasi terbaik.

RER dan GDP dalam logaritma.

$\beta, \gamma, \varphi=$ parameter dari masing-masing variabel pada setiap persamaan

Untuk menguji perbedaan respon ketika ada perubahan nilai tukar rupiah atas dollar AS terhadap impor dan ekspor Indonesia terhadap AS, maka model VAR di atas diaplikasikan dengan mengganti variabel transaksi berjalan relatif (CA) dengan impor dan ekspor berturut-turut. Respon tersebut diidentifikasi dengan berdasarkan horison waktu tertentu (20 kuartal).

\section{III.5. Model ECM dan Kointegrasi}

Penggunaan model jangka panjang untuk mengukur elastisitas perubahan kurs rupiah terhadap dollar AS dan GDP riil relatif terhadap neraca transaksi berjalan relatif Indonesia terhadap AS dibentuk model kointegrasi sebagai berikut

$\mathrm{CA}_{\mathrm{t}}=\gamma_{0}+\gamma_{1} \mathrm{RER}_{\mathrm{t}}+\gamma_{2} \mathrm{RGDP}_{\mathrm{t}}$

CA dalam rasio, RER dan RGDP dalam logaritma

Dengan penerapan model dinamis jangka panjang yang menggunakan model koreksi kesalahan (ECM) maka spesifikasi modelnya disusun sebagai berikut :

$$
\mathrm{DCA}_{\mathrm{t}}=\beta_{0}+\beta_{1} \mathrm{DRER}_{\mathrm{t}}+\beta_{2} \mathrm{DGDP}_{\mathrm{t}}+\beta_{3} \mathrm{RER}_{\mathrm{t}-1}+\beta_{4} \mathrm{GDP}_{\mathrm{t}-1}+\beta_{5} \mathrm{ECT}
$$

Keterangan :

$$
\mathrm{ECT}=\mathrm{RER}_{\mathrm{t}-1}+\mathrm{RGDP}_{\mathrm{t}-1}-\mathrm{CA}_{\mathrm{t}-1}
$$

Spesifikasi model di atas akan valid atau sahih jika koefisien ECT (error correction term) secara statistik signifikan dan memiliki tanda positif. Koefisien ECT bernilai antara 0 sampai dengan 1. Koefisien atau parameter ECT ini selanjutnya dapat digunakan untuk mengestimasi parameter-parameter jangka panjangnya dalam menganalisis perilaku transaksi berjalan relatif Indonesia. 


\section{ANALISIS DATA DAN HASIL PENELITIAN}

\section{IV.1. Stasioneritas Data}

Uji stasioneritas data dilakukan dahulu sebelum mengidentifikasi hubungan kointegrasi variabel-variabel yang diteliti. Selain itu uji akar-akar unit dilakukan karena perlunya uji stasioneritas data sebagai syarat diterapkannya VAR sehingga estimasi dan pengujian hipotesisnya menjadi valid. Syarat diterapkannya VAR adalah datanya stasioner pada derajat nol, dan jika tidak stasioner pada derajat nol sepanjang masih berkointegrasi maka dapat diterapkan VAR.

Tabel 1. Hasil Uji Akar-akar Unit Variabel Dalam Perbedaan Pertama (Uji Dengan Intersep Tanpa Trend)

\begin{tabular}{|c|c|c|c|c|c|c|}
\hline \multirow[t]{2}{*}{ Variabel } & \multicolumn{3}{|c|}{$\begin{array}{c}\text { Augmented Dickey-Fuller (ADF) } \\
\text { Test }\end{array}$} & \multicolumn{3}{|c|}{ Phillips-Perron (PP) Test } \\
\hline & $\begin{array}{l}\text { ADF Test } \\
\text { Statistic }\end{array}$ & $\begin{array}{c}\text { Nilai } \\
\text { Kritis }(\alpha \\
=5 \%), \\
\mathrm{N}=55, \\
\mathrm{Lag}=2\end{array}$ & Keterangan & $\begin{array}{l}\text { PP Test } \\
\text { Statistic }\end{array}$ & $\begin{array}{c}\text { Nilai } \\
\text { Kritis }(\alpha \\
=5 \%), \\
\mathrm{N}=57, \\
\text { Lag }=1\end{array}$ & Keterangan \\
\hline $\mathrm{CA}$ & $-5,8905$ & $-2,9157$ & Stasioner & $-12,1185$ & $-2,9137$ & Stasioner \\
\hline LRER & $-3,8584$ & $-2,9157$ & Stasioner & $-4,7623$ & $-2,9137$ & Stasioner \\
\hline LGDP & $-3,7116$ & $-2,9157$ & Stasioner & $-5,3969$ & $-2,9137$ & Stasioner \\
\hline LX & $-5,2855$ & $-2,9157$ & Stasioner & $-7,4732$ & $-2,9137$ & Stasioner \\
\hline LM & $-5,4449$ & $-2,9157$ & Stasioner & $-9,6866$ & $-2,9137$ & Stasioner \\
\hline
\end{tabular}

Sumber : Analisis data

Dari hasil uji ditunjukkan bahwa hampir semua serial data yang diamati stasioner pada derajat satu sebagaimana hasil pada tabel 1 dan tidak stasioner pada derajat nol. Uji stasioneritas data dilakukan dengan uji akar-akar unit dengan Augmented Dickey-Fuller (ADF) Test dan Phillips-Perron (PP) Test. Uji dengan Phillips-Perron (PP) Test digunakan untuk melengkapi uji dengan uji ADF pada saat uji ini memiliki kelemahan terutama terhadap adanya perubahan besar karena adanya structural breaks dalam serial data.

\section{IV.2. Kointegrasi Variabel-Variabel yang Diteliti}

Hasil pengujian pada seri variabel transaksi berjalan relatif, nilai tukar rupiah dan GDP riil dapat ditunjukkan pada tabel berikut ini. 
Tabel 2. Hasil Uji Kointegrasi dengan Johansen Test Data

(Asumsi Uji : No Deterministic Trend in the Data, Intercept, and No Trend)

\begin{tabular}{|c|c|c|c|c|}
\hline \multirow{2}{*}{$\begin{array}{c}\text { Serial } \\
\text { Data }\end{array}$} & \multicolumn{3}{|c|}{ Likelihood Ratio (LR) } & \multirow[t]{2}{*}{ Hasil Pengujian } \\
\hline & $\begin{array}{l}\text { Hypothesis } \\
\text { of no } \\
\text { cointegration } \\
(r=0)\end{array}$ & $\begin{array}{l}\text { Hypothesis } \\
\text { of one } \\
\text { cointegration } \\
\text { relation } \\
(r=1)\end{array}$ & $\begin{array}{l}\text { Hypothesis } \\
\text { of two } \\
\text { cointegration } \\
\text { relation } \\
(r=2)\end{array}$ & \\
\hline $\begin{array}{l}\text { CA } \\
\text { LRER } \\
\text { LGDP } \\
\end{array}$ & $45,95001 * *$ & 14,31880 & 4,160212 & $\begin{array}{l}\text { Uji LR mengindikasikan } \\
1 \text { persamaan kointegrasi } \\
\text { pada tingkat keyakinan } \\
5 \%\end{array}$ \\
\hline $\begin{array}{l}\text { LX } \\
\text { LRER } \\
\text { LGDP }\end{array}$ & $47,83080 * *$ & 17,97058 & 4,726390 & $\begin{array}{l}\text { Uji LR mengindikasikan } \\
1 \text { persamaan kointegrasi } \\
\text { pada tingkat keyakinan } \\
5 \%\end{array}$ \\
\hline $\begin{array}{l}\text { LM } \\
\text { LRER } \\
\text { LGDP }\end{array}$ & $45,29080 * *$ & 18,90107 & 5,320213 & $\begin{array}{l}\text { Uji LR mengindikasikan } \\
1 \text { persamaan kointegrasi } \\
\text { pada tingkat keyakinan } \\
5 \%\end{array}$ \\
\hline
\end{tabular}

Sumber : Analisis data

Dari estimasi hubungan kointegrasi dari variabel-variabel yang datanya tidak stasioner secara individual pada tabel 2 menghasilkan hubungan kointegrasi pada setiap model sesuai dengan serial data yang diteliti. Oleh karena ada hubungan kointegrasi pada variabel-variabel tersebut maka penelitian ini dapat menerapkan model VAR.

\section{IV.3. Hubungan Kausalitas}

Uji kausalitas yang dilakukan terhadap semua variabel yang diamati pada periode penelitian ini memperoleh hasil uji yang selengkapnya disajikan pada tabel berikut. 
Tabel 3. Hasil Uji Kausalitas antar Variabel dengan Granger Test

\begin{tabular}{|l|c|c|c|}
\hline \multirow{2}{*}{ Hipotesis nol $\left(\mathrm{H}_{0}\right)$} & \multicolumn{3}{|c|}{ Hasil Uji Kausalitas (Granger Test) } \\
& dengan Lag $=4, \mathrm{~N}=54$ & \\
\cline { 2 - 4 } & F Statistik & Probabilitas & Keterangan \\
\hline LRER tidak menyebabkan CA & $5,44620^{*}$ & 0,00116 & Menolak $\mathrm{H}_{0}$ \\
\hline CA tidak menyebabkan LRER & 1,63576 & 0,18181 & Menerima $\mathrm{H}_{0}$ \\
\hline LGDP tidak menyebabkan CA & $6,86312^{*}$ & 0,00021 & Menolak $\mathrm{H}_{0}$ \\
\hline CA tidak menyebabkan LGDP & 0,92246 & 0,45931 & Menerima $\mathrm{H}_{0}$ \\
\hline LGDP tidak menyebabkan LRER & 1,74826 & 0,15610 & Menerima $\mathrm{H}_{0}$ \\
\hline LRER tidak menyebabkan LGDP & 2,54700 & 0,05223 & Menerima $\mathrm{H}_{0}$ \\
\hline LRER tidak menyebabkan LX & 1,59317 & 0,19256 & Menerima $\mathrm{H}_{0}$ \\
\hline LX tidak menyebabkan LRER & 1,42545 & 0,24103 & Menerima $\mathrm{H}_{0}$ \\
\hline LGDP tidak menyebabkan LX & 1,06648 & 0,38419 & Menerima $\mathrm{H}_{0}$ \\
\hline LX tidak menyebabkan LGDP & 1,15263 & 0,34433 & Menerima $\mathrm{H}_{0}$ \\
\hline LRER tidak menyebabkan LM & 1,61332 & 0,18740 & Menerima $\mathrm{H}_{0}$ \\
\hline LM tidak menyebabkan LRER & 2,45724 & 0,05908 & Menerima $\mathrm{H}_{0}$ \\
\hline LGDP tidak menyebabkan LM & 1,78084 & 0,14934 & Menerima $\mathrm{H}_{0}$ \\
\hline LM tidak menyebabkan LGDP & 1,80313 & 0,14488 & Menerima $\mathrm{H}_{0}$ \\
\hline
\end{tabular}

* : signifikan pada $\alpha=5 \%$

Sumber : Analisis data

Hasil uji kausalitas antara variabel transaksi berjalan dengan nilai tukar memang menunjukkan adanya penyebab transaksi berjalan Indonesia oleh nilai tukar rupiah. Hasil itu menunjukkan bahwa periode surplus transaksi berjalan (1997.I - 2004.II) ditandai dengan rata-rata depresiasi rupiah yang jauh lebih besar dibanding pada periode defisit transaksi berjalan (1990.I - 1997.IV). Transaksi berjalan disebabkan oleh nilai tukar rupiah namun pengaruhnya lebih pada perubahan impor daripada kenaikan ekspornya yang menentukan transaksi berjalan Indonesia terutama semenjak krisis atau pada periode surplus transaksi berjalan. Di lain pihak depresiasi tidak cukup mendorong ekspor Indonesia karena penyesuaian harga domestik di dalam negeri akibat depresiasi rupiah itu sendiri melalui inflasi telah menurunkan daya saing produk Indonesia sehingga produk domestik menjadi tidak kompetitif lagi.

Jika uji kausalitas dilakukan terhadap kedua variabel tersebut untuk masingmasing periode (sebelum dan sesudah krisis) maka transaksi berjalan tidak disebabkan oleh nilai tukar rupiah (F statitistik masing-masing 0,85808 dan 0,68203 dengan probabilitas 0,50659 dan 0,61395 ). Uji kausalitas antara transaksi berjalan Indonesia relatif dengan nilai tukar rupiah terhadap dollar AS tidak menemukan adanya penyebab oleh nilai tukar terhadap transaksi berjalan baik pada periode defisit (sebelum krisis) maupun surplus transaksi berjalan Indonesia (setelah krisis).

Selain itu, hasil uji juga menunjukkan bahwa perubahan GDP riil relatif Indonesia - Amerika Serikat dapat menyebabkan perubahan transaksi berjalan relatifnya. Perubahan tersebut terjadi melalui impornya terutama pada periode krisis atau periode surplus transaksi berjalan relatif. Karena perkembangan 
transaksi berjalan relatif Indonesia lebih banyak ditentukan oleh perubahan impornya dan impor sendiri dipengaruhi oleh GDP riil, maka transaksi berjalan relatif Indonesia cukup dominan disebabkan oleh perubahan GDP riil relatifnya.

Hasil uji juga menunjukkan tidak adanya hubungan kausalitas antara nilai tukar rupiah dengan ekspor nonmigas Indonesia ke Amerika Serikat. Artinya bahwa ekspor Indonesia tidak disebabkan oleh depresiasi atau apresiasi rupiah. Jadi depresiasi rupiah terhadap dollar AS tidak mampu mendorong ekspor nonmigas Indonesia ke Amerika Serikat. Produk ekspor Indonesia menjadi tidak kompetitif lagi meskipun rupiah mengalami depresiasi. Tingginya harga domestik karena tingginya biaya produksi akibat ekonomi biaya tinggi telah menjadi penyebab hilangnya daya saing produk Indonesia. Terkikisnya daya saing ekspor Indonesia juga karena cepatnya penyesuaian harga domestik yang terlalu tinggi akibat depresiasi rupiah terhadap dollar Amerika Serikat itu sendiri yang menyebabkan inflasi melalui imported inflation dari barang-barang modal, bahan baku dan perantara yang diimpor untuk kegiatan produksi di dalam negeri.

Variabel impor Indonesia juga tidak disebabkan oleh nilai tukar rupiah dan GDP riil. Namun jika uji tersebut dilakukan khusus untuk periode setelah krisis dengan tenggang (lag) waktu yang sama (4 kuartal), nampak adanya GDP riil sebagai penyebab impor Indonesia oleh GDP riil relatif ( $F$ statistik $=3,98882$ dan probabilitas $=0,01629$ ). Pada periode krisis atau periode surplus transaksi berjalan relatif, turunnya GDP riil relatif Indonesia - Amerika Serikat menyebabkan turunnya impor nonmigas Indonesia dari Amerika Serikat.

\section{IV.4. Hasil Estimasi Model VAR}

Estimasi model VAR terhadap variabel yang diteliti memperoleh hasil pada tabel berikut.

Tabel 4. Hasil Estimasi VAR dengan Lag $=4$ yang Menunjukkan Variabelvariabel Lag yang Signifikan pada $\alpha=5 \%$.

\begin{tabular}{|c|c|c|c|}
\hline \multirow{3}{*}{$\begin{array}{c}\text { Model } \\
\text { Transaksi } \\
\text { Berjalan }\end{array}$} & $\mathrm{CA}$ & LRER & LGDP \\
\hline & $\mathrm{CA}(\mathrm{t}-4)(+)$ & $\operatorname{LRER}(\mathrm{t}-1)(+)$ & $\operatorname{LRER}(\mathrm{t}-1)(-)$ \\
\hline & $\operatorname{LGDP}(\mathrm{t}-3)(-)$ & & $\operatorname{LRER}(\mathrm{t}-2)(+)$ \\
\hline \multirow{4}{*}{$\begin{array}{l}\text { Model } \\
\text { Ekspor }\end{array}$} & $\mathrm{LX}$ & LRER & LGDP \\
\hline & $\mathrm{LX}(\mathrm{t}-1)(+)$ & $\operatorname{LRER}(\mathrm{t}-1)(+)$ & $\operatorname{LRER}(\mathrm{t}-1)(-)$ \\
\hline & $\mathrm{LX}(\mathrm{t}-4)(+)$ & $\operatorname{LRER}(\mathrm{t}-4)(+)$ & $\operatorname{LRER}(\mathrm{t}-2)(+)$ \\
\hline & $\operatorname{LRER}(\mathrm{t}-4)(+)$ & $\operatorname{LGDP}(t-4)(+)$ & \\
\hline \multirow{5}{*}{$\begin{array}{l}\text { Model } \\
\text { Impor }\end{array}$} & LM & LRER & LGDP \\
\hline & $\operatorname{LM}(\mathrm{t}-1)(+)$ & $\operatorname{LM}(t-2)(+)$ & $\operatorname{LM}(\mathrm{t}-2)(-)$ \\
\hline & & $\operatorname{LRER}(\mathrm{t}-1)(+)$ & $\operatorname{LRER}(\mathrm{t}-1)(-)$ \\
\hline & & $\operatorname{LRER}(\mathrm{t}-4)(+)$ & $\operatorname{LRER}(\mathrm{t}-2)(+)$ \\
\hline & & $\operatorname{LGDP}(\mathrm{t}-4)(+)$ & $\operatorname{LGDP}(\mathrm{t}-2)(+)$ \\
\hline
\end{tabular}

(+) berpengaruh positif, (-) berpengaruh negatif

Sumber : Analisis data 
Hasil estimasi dengan model VAR menunjukkan bahwa nilai tukar rupiah riil dengan lag 4 kuartal tidak berpengaruh pada transaksi berjalan relatif. Demikian pula sebaliknya, transaksi berjalan relatif tidak berpengaruh terhadap nilai tukar rupiah riil. Hasil ini sejalan dengan tidak adanya hubungan kausalitas antara keduanya bahkan bersifat independen pada pengujian masing-masing periode (sebelum dan sesudah krisis).

Sementara itu perubahan GDP riil relatif menyebabkan perubahan transaksi berjalan relatif dengan arah berlawanan. Penurunan transaksi berjalan relatif disebabkan oleh kenaikan GDP riil relatif Indonesia terhadap Amerika Serikat pada 3 kuartal sebelumnya, demikian pula sebaliknya. Jadi kenaikan GDP riil relatif yang mendorong kenaikan impor bagi Indonesia menyebabkan turunnya transaksi berjalan relatif. Sementara itu tekanan nilai tukar rupiah riil pada kuartal sebelumnya mendorong nilai tukar rupiah riil untuk terdepresiasi, begitu pula sebaliknya. 
Response to One S.D. Innovations \pm 2 S.E.
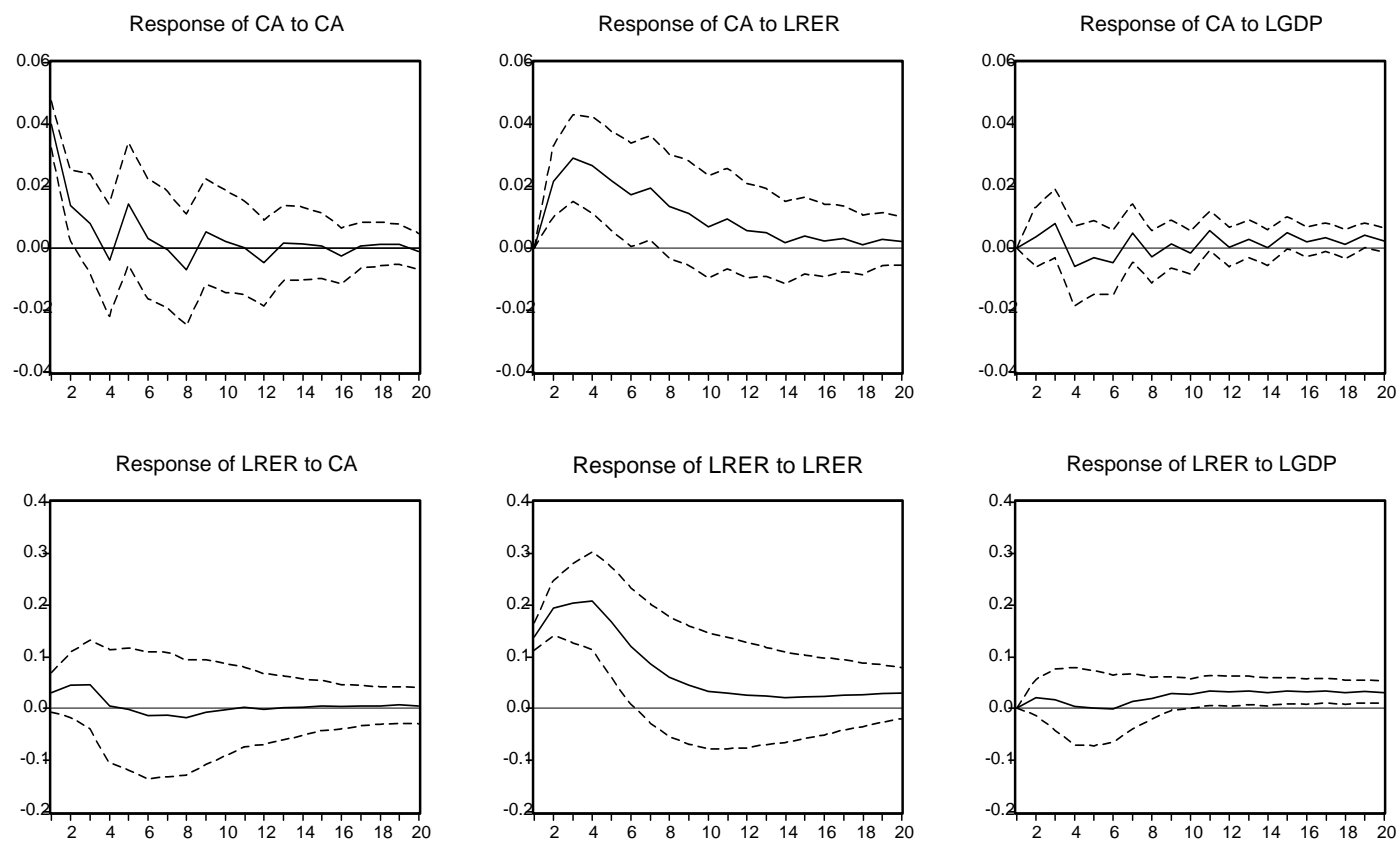

Response of LGDP to CA

Response of LGDP to LRER
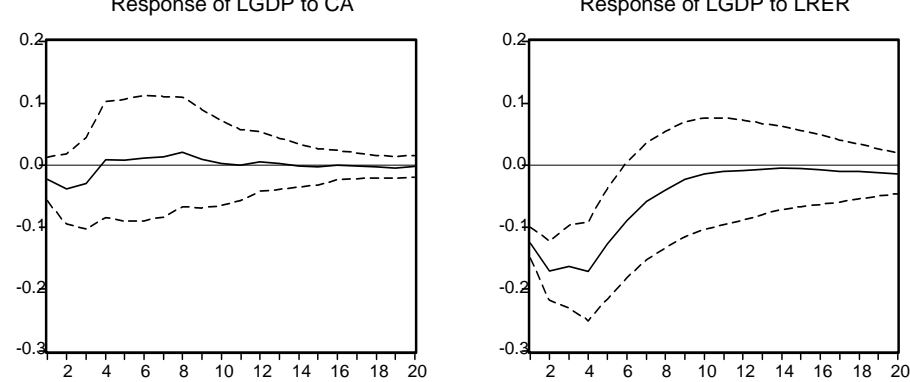

Response of LGDP to LGDP

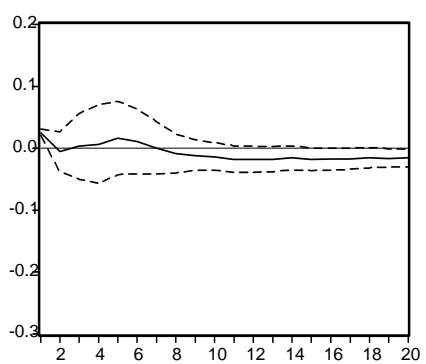

Sumber : Analisis data

Gambar 3. Impulse Response antara Variabel Transaksi Berjalan Relatif, Nilai Tukar Rupiah dan GDP Riil

Pada sebelah kiri dari gambar 3 menunjukkan efek atau pengaruh dari kenaikan satu poin persentase transaksi berjalan relatif terhadap ketiga variabel yaitu transaksi berjalan relatif, nilai tukar riil dan GDP riil relatif. Pada bagian tengah menunjukkan efek dari kenaikan satu persen nilai tukar rupiah riil terhadap ketiga variabel dan bagian kanan menunjukkan efek kenaikan satu persen GDP riil relatif terhadap ketiga variabel.

Depresiasi rupiah (jumlah rupiah per dollar AS semakin meningkat) direspon lemah oleh transaksi berjalan pada kuartal-kuartal pertama. Sementara depresiasi rupiah justru direspon negatif oleh variabel GDP riil dan berangsur hilang setelah lebih dari 20 kuartal. Kenaikan GDP riil relatif direspon oleh 
transaksi berjalan secara berfluktuasi dan cenderung lemah sampai lebih dari 20 kuartal. Sementara oleh nilai tukar dan dan GDP riil sendiri langsung direspon lemah pada kuartal-kuartal awal. Dengan demikian berdasarkan impulse response yang umumnya lemah dan berfluktuasi serta cepat menghilang efeknya menunjukkan bahwa terdapat hubungan yang lemah khususnya antara transaksi berjalan relatif, nilai tukar rupiah dan GDP riil.

Dari hasil estimasi model ekspor pada tabel 4 ditunjukkan adanya momentum pertumbuhan ekspor yang berlanjut dalam beberapa kuartal setidaknya selama satu tahun baik meningkat atau menurun. Hal yang sama juga terjadi pada impor. Sementara itu, meskipun perubahan nilai tukar tidak berpengaruh terhadap ekspor menurut uji kausalitas, namun dengan uji VAR perubahan nilai tukar rupiah berpengaruh terhadap ekspor Indonesia ke Amerika Serikat meskipun diperlukan lag waktu yang relatif lama yaitu 4 kuartal. Depresiasi rupiah tidak serta merta diikuti dengan meningkatnya ekspor Indonesia, namun diperlukan waktu 4 kuartal untuk mempengaruhi ekspor tersebut. Hasil estimasi ini menunjukkan tidak adanya pengaruh yang kuat dari perubahan nilai tukar terhadap kinerja ekspor nonmigas meskipun memerlukan lag waktu. Bahkan dengan uji kausalitas keduanya tidak memiliki hubungan kausalitas yang signifikan.

\section{IV.5. Hasil Estimasi Model Kointegrasi}

Hasil estimasi model kointegrasi mengindikasikan bahwa dalam jangka panjang nilai tukar rupiah riil tidak signifikan berpengaruh terhadap transaksi berjalan, sementara GDP riil signifikan berpengaruh negatif terhadap transaksi berjalan. Dalam penelitian ini GDP riil sangat menentukan permintaan impor sehingga pada gilirannya berpengaruh pada transaksi berjalan.

Tabel 5. Hasil Estimasi Model Kointegrasi

Variabel Dependen Transaksi Berjalan Relatif (CA)

\begin{tabular}{|c|c|c|c|}
\hline Variabel & Koefisien & t-statistik & Probabilitas \\
\hline C & $-0,8724$ & $-11,6855$ & 0,0000 \\
\hline LRER & 0,0260 & 1,0749 & 0,2871 \\
\hline LGDP & $-0,1185$ & $-2,6359$ & 0,0109 \\
\hline $\mathrm{R}^{2}=0,8188$ \\
\hline \multicolumn{4}{|l}{ Durbin Watson $=1,5277$} \\
\hline \multicolumn{4}{|l}{ F-Statistik = 124,2602 (Probabilitas 0,0000$)$} \\
\hline
\end{tabular}

Sumber : Analisis data

Dari hasil estimasi model kointegrasi di atas meskipun ketiga variabel tidak stasioner pada derajat nol sebagaimana uji akar-akar unit sebelumnya, namun kombinasi linear dari ketiganya menunjukkan adanya kointegrasi. Ketiga variabel berkointegrasi sebagaimana hasil ini juga sejalan dengan hasil uji kointegrasi dengan Johansen test. Dengan demikian ketiga variabel yang berkointegrasi mengartikan bahwa ketiganya memiliki hubungan jangka panjang namun tidak 
berarti keseluruhannya secara individu memiliki pengaruh yang signifikan. Hasil ini mengindikasikan bahwa variabel nilai tukar rupiah baik tanpa maupun dengan tenggang waktu (lag) tidak signifikan berpengaruh terhadap transaksi berjalan relatif sebagaimana hasil regresi VAR dan kointegrasi serta uji kausalitas dengan memisahkan dua periode. Sementara itu variabel GDP riil signifikan berpengaruh negatif terhadap transaksi berjalan relatif baik tanpa maupun dengan lag waktu berdasarkan hasil regresi kointegrasi, VAR serta uji kausalitas untuk keseluruhan periode penelitian.

Dengan demikian hasil ini menolak hipotesis dan tidak memenuhi teori efek kurva-J dalam menjelaskan perilaku transaksi berjalan karena menurut teori ini perubahan nilai tukar mendorong secara positif perubahan transaksi berjalan dan GDP riil. Artinya nilai tukar rupiah merupakan faktor minor dalam menjelaskan perilaku transaksi berjalan relatif Indonesia dan masih banyak faktor lain yang dominan mempengaruhi perilaku transaksi berjalan dan GDP riil. Khususnya di Indonesia faktor-faktor lain yang ikut berpengaruh antara lain cukup tingginya efek nilai tukar terhadap inflasi domestik (bersifat inflasioner) ketika kegiatan produksi domestik bergantung pada barang impor, ekonomi biaya tinggi yang disebabkan masalah infrastruktur dan pungutan-pungutan liar, serta kebijakan penyesuaian harga dan pendapatan.

\section{IV.6. Hasil Estimasi Model ECM}

Sebagaimana pada hasil regresi model ECM, perubahan nilai tukar dan GDP riil tidak signifikan mempengaruhi perubahan transaksi berjalan pada periode yang sama. Perubahan transaksi berjalan dipengaruhi secara signifikan dan negatif oleh nilai tukar rupiah dan GDP riil kuartal sebelumnya. Hasil ini tentunya menunjukkan adanya efek kurva-J pada jangka pendek, namun selanjutnya nilai tukar dan GDP riil tidak berpengaruh positif bagi transaksi berjalan dalam jangka panjang sebagaimana hasil estimasi model kointegrasi. Hasil estimasi dengan model ECM ini memperkuat bukti lemahnya efek kurva-J dalam perilaku transaksi berjalan Indonesia pada periode penelitian.

Tabel 6. Hasil Estimasi Model Error Correction Mechanism (ECM) Variabel Dependen : DCA

\begin{tabular}{|c|c|c|c|}
\hline Variabel & Koefisien & t-statistik & Probabilitas \\
\hline C & $-0,6879$ & $-4,8249$ & 0,0000 \\
\hline DLRER & 0,2442 & 1,5341 & 0,1312 \\
\hline DLGDP & 0,1887 & 1,0835 & 0,2837 \\
\hline LRER (-1) & $-0,7403$ & $-5,3994$ & 0,0000 \\
\hline LGDP (-1) & $-0,8581$ & $-5,2840$ & 0,0000 \\
\hline ECT & 0,7509 & 5,4529 & 0,0000 \\
\hline $\mathrm{R}^{2}=0,4816$ \\
\hline Durbin Watson = 2,0988 \\
\hline F-Statistik = 9,4759 (Probabilitas 0,0000) \\
\hline
\end{tabular}

Sumber : Analisis data 
Model di atas akan valid atau sahih karena koefisien ECT (error correction term) secara statistik signifikan dan memiliki tanda positif. Koefisien ECT di atas bernilai antara 0 sampai dengan 1 . Parameter ECT ini selanjutnya dapat digunakan untuk mengestimasi parameter-parameter jangka panjangnya dalam menganalisis perilaku transaksi berjalan relatif Indonesia terhadap AS atas perubahan nilai tukar rupiah dan tingkat pendapatan relatifnya. Hasil ini tidak berbeda dengan hasil estimasi persamaan kointegrasi pada bagian sebelumnya.

\section{PENUTUP}

\section{V.1. Kesimpulan}

Penelitian ini menemukan bukti lemah adanya efek kurva-J pada neraca transaksi berjalan di Indonesia karena hasil-hasil empirik dengan beberapa uji dan model menolak hipotesis kurva-J. Studi empirik ini menemukan sedikit bukti bahwa depresiasi rupiah menyebabkan defisit transaksi berjalan secara bilateral antara Indonesia dengan AS dalam jangka pendek, dan tidak menemukan bukti adanya pengaruh nilai tukar rupiah terhadap neraca transaksi berjalan Indonesia dalam jangka panjang.

Hal menarik dari hasil penelitian ini bahwa hasil empirik menunjukkan adanya bukti yang tidak sesuai dengan teori standar kurva-J. Hasil ini sejalan dengan hasil penelitian oleh Leonard dan Stockman (2001). Hasil penelitian ini juga sejalan dengan hasil penelitian Moffet (1989), Rose dan Yellen (1989) di Amerika Serikat, serta Calderon et al. (2000) di negara-negara berkembang serta Lee dan Chinn (1998) di Inggris. Dengan demikian hasil empirik ini merupakan tantangan bagi teori dan kebijakan ekonomi internasional. Nilai tukar rupiah merupakan faktor minor dalam menjelaskan perilaku transaksi berjalan relatif Indonesia dan masih banyak faktor lain yang dominan mempengaruhi perilaku transaksi berjalan dan GDP riil yang berkaitan dengan kondisi internal terutama sektor riil di Indonesia.

\section{V.2. Saran}

Berdasarkan temuan empirik dalam penelitian ini, maka disarankan bagi pemerintah bahwa dalam menjalankan kebijakan untuk mendorong ekspor dan mengendalikan impor dalam rangka mengoreksi defisit transaksi berjalan tidak semata-mata dengan tindakan yang mengarah untuk mendorong atau membiarkan depresiasi rupiah tanpa disertai dengan kebijakan untuk membenahi kondisi internal (sektor riil) Indonesia.

Sebagai konsekuensi dari kebijakan nilai tukar mengambang yang tidak bisa dipungkiri telah membuat kesulitan ekonomi bagi kegiatan produksi di dalam negeri, terbukti bahwa fluktuasi nilai tukar tidak menguntungkan bagi ekspor, maka otoritas moneter perlu tetap memberikan perhatian lebih terhadap kebijakan untuk menjaga dan mengendalikan stabilitas nilai tukar rupiah dalam rangka 
mendorong sektor riil (produksi) di dalam negeri dan memberikan kepastian usaha bagi eksportir Indonesia.

Selanjutnya untuk pengembangan studi berikutnya perlu adanya penjelasan lebih lanjut dari teori kurva-J dan asumsi-asumsi yang digunakan sesuai dengan kondisi di negara-negara yang berbeda dalam aplikasi penelitian-penelitian lanjutannya. Karena nilai tukar dalam penelitian ini hanya merupakan faktor minor dan didasarkan pada teori standar kurva-J, maka pada penelitian-penelitian selanjutnya dapat ditambahkan atau digunakan variabel-variabel lain sebagai proksi dalam menjelaskan perilaku transaksi berjalan.

\section{DAFTAR PUSTAKA}

Basri, Muhammad Chatib. "Sektor Riil Masih Tiarap". Kompas Edisi 20 Juli 2003.

Batiz, Francisco L. Rivera dan Luis A. Rivera Batiz, (1994), International Finance and Open Economy Macroeconomics, Second Edition, Macmillan Publishing Company, New York .

Calderon, Cesar, Alberto Chong, dan Norman Loaya. "Determinants of Current Account Deficits in Developing Countries" http://Econ.worldbank.org/working-papers/2398, 2000.

Denburg, Thomas F, (1985), Macroeconomics, McGraw-Hill, Inc., New York.

Devkota, Satis Candra. "Impact of Exchange Rate Cange on Foreign Trade Balance in Nepal” http://econwpa.wustl.edu, 2004.

Djiwandono, J. Sudradjad. "Nasib Rupiah dan Sistim Nilai Tukar" http://www.pacific.net.id/pakar/sj/010407.html.

Egle, R.F. dan C.W.J. Granger, (1991), Long-Run Economic Relationships : Reading in Cointegration, Oxford University Press, New York.

Eichenbaum, Martin dan Charles Evans. "Some Empirical Evidence on the Effects of Monetary Policy Shocks on Exchange Rates", Quarterly Journal of Economics 110,1995.

Gujarati, Damodar N., (2003), Basic Econometrics, Fourth Edition, McGrawHill, Singapore.

Hendry, David F., (1995), Dynamic Econometrics, Oxford University Press, New York.

Insukindro. "Model Koreksi Kesalahan untuk Permintaan Impor Bahan Bakar Minyak Indonesia", Jurnal Ekonomi dan Bisnis Indonesia, Tahun V. No. 1.

Irma, Adelman. "Financial Crises-Causes, Consequences and Remedies", University of California at Berkeley Working Paper, No. 889, 1999.

Johansen, Soren, (1995), Lixelihood-Based Inference in Cointegrated Vector Autoregressive Models, Oxford University Press, New York.

Koray, Faik dan Douglas McMillin. "Monetary Shocks, the Exchange Rate, and Trade Balance", Journal of International Money and Finance No.18, 1999.

Kreinin, Mordechai E, (2002), International Economics : A Policy Approach, Ninth Edition, Thomson Learning, Inc. 
Krugman, Paul R. dan R.E. Baldwin. "The Persistence of the U.S. Trade Deficit" Brookings Papers on Economics Activity, 1987.

Liew, Khim-Sen, Kian-Ping Lim dan Huzaimi Hussain. "Exchange Rate and Trade Balance Relationship : The Experience of ASEAN Countries" http://econwpa.wustl.edu, 2003.

Lee, Jaewoo dan Menzie D. Chinn. "The Current Account and the Real Exchange Rate : A Structural VAR Analysis of Major Currencies", NBER Working Paper 649, 1988.

Ma, Zihui dan Leonard Cheng. "The Effects of Financial Crises on International Trade", NBER Working Paper No. w10172, 2003.

Moffett, Michael H. "The J-Curve Revisited : An Empirical Examination for the United States", Journal of International Money and Finance 8, 1989.

Rajan, Ramkishen S. "The Limits of Asian Currency Flexibility", Bisnis Times, October 9, 2003.

Rose, Andrew K. dan Janet L. Yellen. "Is There a J-Curve ?", Journal of Monetary Economics 24, 1989.

Salvatore, Dominick, (1996), International Economics, Fifth Edition, PrenticeHall, New Jersey.

Stock, James H. dan Mark W. Watson. "Vector Autoregressions, Research Associates", National Bureau of Economic Research, Cambiridge, Massachusetts, 2001.

Verbeek, Marno, (2000), A Guide to Modern Econometrics, John Wiley \& Sons, Ltd., New York.

Waluyo, Doddy Budi dan Benny Siswanto. "Peranan Kebijakan Nilai Tukar Dalam Era Deregulasi dan Globalisasi", Buletin Ekonomi Moneter dan Perbankan, Bank Indonesia, Vol. 1, No.1, Juli 1998. 


\section{BIODATA PENELITI UTAMA}

1. $\mathrm{Na} \mathrm{m} \mathrm{a}$

2. Tempat dan Tanggal Lahir : Magelang, 24 Oktober 1973

3 Pekerjaan

4. Alamat Rumah

5. Alamat Kantor

6. Pendidikan :
: Arintoko

: Staf Pengajar FE UTY

: Perumahan Gesikan No. 9 RT 06 RW 03 Sidoarum, Godean, Sleman, Yogyakarta HP 08122761335 e-mail : arintokoz@yahoo.co.id

: Fakultas Ekonomi UTY Jl. Glagah Sari No. 63 Umbulharjo, Yogyakarta 55164

Telp. (0274) 373955 Fax. (0274) 381212

\begin{tabular}{|l|l|l|c|}
\hline No & \multicolumn{1}{|c|}{ Pendidikan } & \multicolumn{1}{|c|}{ Institusi } & Tahun \\
\hline 1 & $\begin{array}{l}\text { Jurusan Ilmu Ekonomi dan Studi } \\
\text { Pembangunan, Fakultas } \\
\text { Ekonomi }\end{array}$ & $\begin{array}{l}\text { Universitas Gadjah } \\
\text { Mada Yogyakarta }\end{array}$ & 1993 - 1998 \\
\hline 2 & $\begin{array}{l}\text { Jurusan Ilmu Ekonomi dan Studi } \\
\text { Pembangunan, Magister Sains, } \\
\text { Program Pasca Sarjana }\end{array}$ & $\begin{array}{l}\text { Universitas Gadjah } \\
\text { Mada Yogyakarta }\end{array}$ & 2002 - 2005 \\
\hline
\end{tabular}

7. Pengalaman Penelitian

7a. Penelitian Individu

\begin{tabular}{|l|l|c|}
\hline No & \multicolumn{1}{|c|}{ Karya Ilmiah } & Waktu \\
\hline 1 & $\begin{array}{l}\text { Analisis Kinerja Industri Pengolahan Terhadap Intensitas } \\
\text { dan Beban Pencemaran Lingkungan : Studi Kasus di } \\
\text { Kabupaten dan Kota Tangerang tahun 1996 } \\
\text { (Skripsi S1 dengan konsentrasi Ekonomi Lingkungan) }\end{array}$ & $1997-1998$ \\
\hline 2 & $\begin{array}{l}\text { Analisis Perilaku Inflasi Jangka Pendek dan Jangka } \\
\text { Panjang Atas Faktor-Faktor Penyebab Utama di Indonesia } \\
\text { Periode 1990.1 - 2001.1 } \\
\text { (Dipublikasikan di KOMPAK FE UTY, Edisi Mei 2002) }\end{array}$ & $\begin{array}{l}\text { 2002 } \\
\text { Bunga Jangka Pendek dan Reserve Aggregates Sebagai } \\
\text { Sasaran Operasional di Indonesia Pada Periode Sebelum } \\
\text { dan Sesudah Krisis Moneter }\end{array}$ \\
\hline 4 & $\begin{array}{l}\text { Pengaruh Perubahan Nilai Tukar Rupiah Terhadap Neraca } \\
\text { Transaksi Berjalan Indonesia, Periode 1990.I - 2004.II } \\
\text { (Kasus Indonesia - Amerika Serikat) }\end{array}$ & 2004 - 2005 \\
\hline
\end{tabular}


7b. Penelitian Kerjasama

\begin{tabular}{|l|l|c|}
\hline No & \multicolumn{1}{|c|}{ Nama Penelitian } & Waktu \\
\hline 1 & $\begin{array}{l}\text { Survei Pengaruh Maraknya Kegiatan Properti terhadap } \\
\text { Investasi, Inflasi, dan Kredit Perbankan di DIY } \\
\text { (Penelitian Kerja Sama LPPM UTY - Bank Indonesia } \\
\text { Yogyakarta) }\end{array}$ & 2004 \\
\hline
\end{tabular}

\section{BIODATA PENELITI II}

1. $\mathrm{N} \mathrm{a} \mathrm{m} \mathrm{a}$

2. Pekerjaan

3. Jabatan Akademik

4. Alamat Kantor
: Dr. Faried Wijaya, MA

: Staf Pengajar FE UGM

: Lektor Kepala

: Gedung Fakultas Ekonomi Universitas Gadjah Mada Lt. 1 Sayap Selatan, Bulaksumur, Yogyakarta 55281. HP 0811282756

Telp. (0274) 378408 (Rumah) 